\title{
Microaggressions as a Barrier to Effective Collaboration Between Teaching Faculty and Academic Librarians: An Analysis of the Results of a U.S. and Canadian Survey
}

Ahmed Alwan, California State University, USA

Joy Doan, Northwestern University, USA

Eric Garcia, California State University, USA

\begin{abstract}
Facilitating effective collaboration with teaching faculty (TF) for the purposes of student success and performance is often a priority for academic librarians (AL). The topic of effective partnerships between these two groups has received a great deal of scholarly attention within the field of library and information science (LIS). However, in practice, harmonious working relationships can be difficult to establish and maintain. This is in part due to the lack of understanding of the role and status of AL by TF. The existing divide between these parties has led to discourse and dismissive actions on the part of TF that may be perceived by some AL as microaggressive. While some work has been done on microaggressions in higher education, little quantitative data exists on status-based microaggressions by TF towards $\mathrm{AL}$ and its effect on collaboration in the context of information literacy (IL). In early 2016, the researchers surveyed U.S. and Canadian AL in order to collect data on perceived status-based microaggressive experiences. Analysis of the data indicates that status-based microaggressions, although not ubiquitous, do exist. Moreover, the data indicates that some librarians may experience more frequent instances of status-based microaggressions based on self-reported demographic characteristics.
\end{abstract}

Keywords: academic librarians; collaboration; equity; information literacy; status-based microaggression; teaching faculty

Publication Type: research article

\section{Introduction}

E ffective collaboration between teaching faculty (TF) and academic librarians (AL) continues to receive a great deal of scholarly attention, as evidenced by the numerous articles, chapters, and books published on the topic (Delaney \& Bates, 2015; Mounce, 2010; Vassilakaki \& Moniarou-Papaconstantinou, 2015). Collaboration and communication between TF and AL can help ensure students' acquisition of the information literacy (IL) skills required to succeed in an academic setting. Although there have not been many statistically significant studies showing that IL instruction has a positive impact on student performance (Kuh \& Gonyea, 2003), several recent studies have begun to provide quantitative support for the positive impact of IL on student academic success (Kot \& Jones, 2015; Stemmer \& Mahan, 2016).

One of the ways in which AL have assisted in improving student performance is through IL 
instruction. However, effective IL instruction often hinges on the willingness of TF to work together with AL. The researchers hypothesize that one major obstacle to such collaboration is status-based microaggressions by TF toward AL, in the context of IL. Status-based microaggressions, like other forms of microaggression (e.g., race, gender, sexuality), may occur when a group or individual is perceived as having a divergent group membership. As with other forms of microaggression, status-based microaggressions can lead to ineffective collaboration and have the potential to breed resentment, confusion, or anger on the part of the target (Sue, 2010). Although these actions may be attributed, in part, to a deficit in TF's understanding of ALs' roles in academia (Badke, 2005), dismissive actions or negative discourse on the part of TF can be categorized as microaggressive based on the definition posited by the leading authority on microaggressions, Derald Wing Sue (2010).

Currently, the only quantitative research on microaggressions in academic libraries focuses on racial and ethnic microaggressions (Alabi, 2015). To date, no quantitative data exists on statusbased microaggressions by TF toward AL. The literature on TF and AL interactions indicates that a variety of issues can impede effective collaboration. Issues can include misunderstandings between the two groups, confusion over roles, superordinate-subordinate culture, and the treatment and perceptions of AL by TF as service staff (e.g., Badke, 2005; Christiansen, Stombler, \& Thaxton, 2004; Given \& Julien, 2005; Julien \& Given, 2003). The latter is particularly significant because perceptions of AL as service providers rather than equal partners is longstanding and pervasive (Nalani Meulemans \& Carr, 2013).

In early 2016, the researchers surveyed AL in the U.S. and Canada to collect data on perceived status-based microaggressive experiences. The overarching purpose of the study was to address the gap in library and information science (LIS) literature on this topic. This study used the concept of microaggression to investigate AL's experiences of dismissive and/or negative treatment based solely on their distinct academic status within higher education.

This article aims to offer insight into AL experiences of status-based microaggressions encountered in an academic setting while interacting with TF. The data was collected using a survey that was distributed via local, national, and international LIS electronic mailing lists specifically geared towards AL in the U.S. and Canada. The researchers conducted data analysis using a simple linear regression analysis (using the statistical analysis software package SPSS), a mean analysis, and response rate analysis to determine if a relationship existed between the demographic data collected and three sections of the survey. The three selected sections focused on the existence of possible status-based microaggressions that AL experienced while interacting with TF in the context of IL instruction.

\section{Literature Review}

\section{Collaboration Between Teaching Faculty and Academic Librarians}

A central goal for $A L$ in postsecondary institutions is to provide IL instruction, which presently serves as a staple of higher education (Given \& Julien, 2005; Julien \& Given, 2003). The relationship between TF and AL remains at the nucleus of IL initiatives (Julien \& Pecoskie, 2009). However, the constant misalignment of these groups' non-competing goals continues to impede the success of this endeavor. The bureaucratic makeup of higher education and misunderstandings between the two groups about their roles in academia account for the underlying division between TF and AL (Badke, 2005; Christiansen et al., 2004; Given \& Julien, 2005; Julien \& Given, 2003; Julien \& Pecoskie, 2009). 
A vast amount of literature exists on the history of academic libraries and their place within the bureaucracy of academia (Budd, 2005; Julien \& Pecoskie, 2009). Despite garnering a great deal of attention, such discussions have not prompted a large-scale restructuring that could place the library in a stronger position in higher education. The lack of measurable change leaves the profession of academic librarianship in the rut of service-oriented work. AL and their academic partners, TF, need to develop methods to elicit change that will eventually bridge the existing disconnect.

The research of Lars Christiansen, Mindy Stombler, and Lyn Thaxton (2004) provides a theoretical framework to discuss the causes of TF's microaggressive behavior toward AL. Their findings rely on two premises. First, the bureaucratic organization of higher education results in limited shared work practices between TF and AL. Second, the "superordinate-subordinate relations" (Christiansen et al., 2004, p. 119) inherent to societal views of traditionally serviceoriented professions influences TF's perception of AL as not producing worthwhile scholarly output. These two factors generate what the authors term an "asymmetrical disconnection" (Christiansen et al., 2004, pp. 117-118) between TF and AL. While both groups may recognize the disconnection, only $\mathrm{AL}$ perceive it to be problematic in their collaborative work in academia (Christiansen et al., 2004).

Collaboration between TF and AL can include working together to develop teaching strategies, pedagogical practices, learning outcomes, models, resources, and tools-all aimed at improving student performance. Christiansen et al. (2004) suggest that while TF respect the service work of $\mathrm{AL}$, they are vastly unaware of ALs' scholarly qualifications, subject expertise, and requirements for tenure and promotion. To rectify the situation, AL should engage in awareness initiatives to inform TF about academic librarianship beyond immediate transactions; in turn, TF should be open and receptive to this kind of learning. As a result, TF may become more inclined to increase collaborative efforts with AL, by way of grant writing, course design, and so on.

In a similar vein, William Badke (2005) concludes that the crux of the misunderstanding between TF and AL lies within the bureaucratic divide set in place by academia. According to Badke, the advancement of cross-departmental and university goals calls for a more authentic approach to collaboration between the two groups. The IL goals of both parties must align to produce symmetry. Moreover, TF should not view the pedagogical goals of AL as obstructive or threatening (Badke, 2005).

The work of Heidi Julien and Jen Pecoskie (2009) expands upon Badke's study. Their qualitative study posits that AL often view TF as the fulcrum within the tertiary relationship between TF, $\mathrm{AL}$, and student success. This practice primarily derives from the organizational culture of higher education and ALs' subordinate behavior when dealing with TF. Their results indicated that many AL view IL instruction time as a "gift" provided by TF (Julien \& Pecoskie, 2009). They conclude that the subservient behavior of AL toward TF exists and that "institutional attitudinal change is necessary for these relationships to be altered and for more significant perceptions about what can be learned from the roles to be constructed" (Julien \& Pecoskie, 2009, p. 152). 


\section{Etymology and Evolution of Microaggressions}

The term "microaggressions" was first outlined by Chester Middlebrook Pierce (1970) in a book chapter entitled "Offensive Mechanisms." Pierce argued that a shift occurred in how racism and discrimination were committed in the era of the Civil Rights Movement versus the time period that followed. He asserted that overt acts of racism transitioned to more subversive and subtle acts. According to Pierce, these subtle acts of discrimination remain just as crippling to individuals as more overt forms. Mary Rowe (1981) furthered Pierce's research on microaggressions by developing the concept of micro-inequality. This concept expanded on microaggressions by providing a broader framework that incorporated women and minorities (Rowe, 1981).

The work of Samuel L. Gaertner and John F. Dovidio (1986) also influenced the modern concept of microaggression. Gaertner and Dovidio suggested that racism remained a prominent part of society even after the decline in overt racism. They argued that when polled, the majority of white Americans believed that racism had declined sharply and in most cases was disappearing. Conversely, when African Americans were polled, they reported that they continued experiencing racism frequently. Gaertner and Dovidio (1986) theorized that expressions of racism had evolved in the U.S.; while open acts of hostility were no longer acceptable and occurred less frequently, subtle forms of racism, which they labeled "aversive-racism" ( $p$. $315)$, continued to permeate society.

The leading scholar on microaggressions, Derald Wing Sue, describes them as common or casual, verbal or nonverbal, status-based slights, snubs, or insults, either intentional or unintentional, that communicate hostile, derogatory, or negative messages toward individuals based solely on marginalized group membership (Sue, 2010; Sue \& Rivera, 2010). What differentiates microaggressions from overt and deliberate acts of discrimination is that the people committing microaggressions often intend no offense or are unaware they are causing harm. Due to the subtle nature of microaggressions and the difficulty of identifying them, Sue et al. (2007) developed a taxonomy for microaggressions that identifies three specific types: microassault, microinsult, and microinvalidation (p. 274). A microassault can be a subtle or explicit biased attitude, belief, or behavior communicated to a marginalized group or person through environmental cues and/or verbalization. Examples can include name-calling, avoidant behavior, and purposeful discriminatory actions.

In other words, people are likely to hold notions of minority inferiority privately and will only display them publicly when they (a) lose control or (b) feel relatively safe to engage in a microassault. (Sue, Capodilupo, Torino, Bucceri, Holder, Nadal, \& Esquilin, 2007, p. 274)

A microinsult is usually more explicit and is meant to demean. This is typically done using interpersonal or environmental communications that convey stereotypes, rudeness, and insensitivity. Examples can include subtle snubs or insulting messages.

When a White employer tells a prospective candidate of color "I believe the most qualified person should get the job, regardless of race" or when an employee of color is asked "How did you get your job?", the underlying message from the perspective of the recipient may be twofold: (a) People of color are not qualified, and (b) as a minority group member, you must have obtained the position through some affirmative action or quota program and not because of ability. (Sue et al., 
2007, p. 274)

Lastly, microinvalidation, which is potentially the most dangerous form of microaggression, involves communications or environmental cues meant to exclude, negate, or nullify the psychological thoughts, feelings, or experiential reality of particular persons or groups. In such a situation, the perpetrator is directly denying or imposing upon the reality of a person or group.

When Asian Americans (born and raised in the U.S.) are complimented for speaking good English or are repeatedly asked where they were born, the effect is to negate their U.S. American heritage and to convey that they are perpetual foreigners. When Blacks are told that "I don't see color" or "We are all human beings," the effect is to negate their experiences as racial/cultural beings (Helms, 1992). When a Latino couple is given poor service at a restaurant and shares their experience with White friends, only to be told “Don't be so oversensitive" or "Don't be so petty," the racial experience of the couple is being nullified and its importance is being diminished. (Sue et al., 2007, pp. 274-275)

\section{Microaggressions in Library and Information Science}

Although some work exists on microaggressions in higher education, an exhaustive examination of the LIS literature has demonstrated that no quantitative data exists on status-based microaggressions in higher education. To date, most research on microaggressions specifically related to AL focuses on race and gender. Jaena Alabi (2015) has led research in this area by studying occurrences of race-based microaggressions experienced by AL. Alabi's study found that many AL who identify as minorities experience microaggressions from their colleagues at an increased rate. There has also been a movement among AL to use Tumblr and Zines (i.e., non-commercial homemade or online publications usually devoted to specialized and often unconventional subject matter) to document and chronicle AL experiences of microaggressions (LIS Microaggressions, n.d.). However, the primary focus of these types of initiatives has been to act as a gallery and repository of anecdotes about all types of microaggressions in libraries. Although useful, these initiatives provide little in the way of substantial data analysis or findings.

\section{Methodology}

To address the gap in the literature, the researchers initiated an empirical study in the form of a survey about status-based microaggressions between TF and AL. The proposed study received institutional review board approval from California State University, Northridge (CSUN), Office of Research and Sponsored Programs in January 2016. For the study, an online survey was developed (using eSurv) and deployed to collect quantitative data on the topic. The target population for recruitment in the survey was AL in the U.S. and Canada. The survey included AL who were tenured or tenure-track, as well as those who did not hold faculty status. The work of Alabi (2015) on racial microaggressions in academic libraries influenced the survey design. However, because Alabi's research was primarily focused on racial microaggressions, it was necessary to significantly modify and adapt the survey questions to focus on status-based microaggressions.

In developing the questions $(\mathrm{Q})$ for the survey, the researchers used a variety of resources. Sources used included Alabi's (2015) work on racial microaggressions in academic libraries, 
Sue's (2010) work on microaggressions, the Microaggressions in Librarianship Tumblr, the literature on TF and AL collaboration, and the researchers' shared anecdotal experiences. Using these sources, the researchers were able to develop examples of situations and interactions between the two parties that could be construed as microaggressive behavior based on status. These interactions and situational experiences then became the basis of the survey questions.

The researchers used purposeful sampling to target applicable survey participants. The survey was distributed via local, national, and international LIS electronic mailing lists specifically geared toward AL in the U.S. and Canada. It was also hoped that this recruitment mechanism would encourage spreading the survey through word of mouth. This resulted in snowball sampling, as AL shared the survey link with their colleagues. One of the benefits of purposeful and snowball sampling was the mitigation of threats to external validity (i.e., the extent that the results of a study can be generalized from a sample to a population), thereby ensuring population generalizability (i.e., the extent to which the results of a study can be generalized to the intended population).

The researchers used a five-point Likert scale for the survey, excluding the personal and professional demographic sections. Participants were provided with a set of options ranging from "strongly agree" to "strongly disagree," as well as from "very frequently" to "never." The survey remained open for four weeks between February and March 2016. During this period, multiple survey completion reminders were provided. The survey consisted of eight (quantitative) sections (see the Appendix), including: "Personal Demographics," "Professional Demographics," "Microaggressions in a Larger Context," "Assumptions of Inferiority," "Classism," "Collaboration for IL Sessions," "Collaboration for Technical Services," and "Strides Towards Effective Collaboration."

1. Personal Demographics. In this section participants were asked personal demographic questions aimed at anonymously assessing age, race, citizenship status, and geographic location.

2. Professional Demographics. In this section participants were asked professional demographic questions aimed at anonymously assessing academic status, level of education, type of institution, and level of experience.

3. Microaggressions in a Larger Context. In this section participants were asked about their familiarity with the concept of microaggression. Respondents were also asked if they believed that this term could be applied to issues beyond race and gender. Finally, participants were asked if they received formal or informal training on how to interact with TF.

4. Assumptions of Inferiority. In this section participants were asked whether they had experienced negative interactions with TF regarding their level of education, scholastic achievements, position, title, and/or intelligence.

5. Classism (i.e., professional status or class). In this section participants were asked about their feelings on and experiences with distinctions made between TF and AL. Additionally, this section measured actions by library administrators and reactions related to reported incidents of classism. 
6. Collaboration for IL Sessions. In this section participants were asked about their varied experiences in collaborating with TF on IL sessions.

7. Collaboration for Technical Services. In this section participants were asked about their varied experiences in collaborating with TF over technical service-based issues.

8. Strides Towards Effective Collaboration. In this section participants were asked about their involvement in curriculum design and scholarly research projects with TF.

To gather critical feedback on the survey, a pretest was initiated to test the instrument before dissemination. The pretest involved a total of seven TF and AL. Individuals were asked to complete the survey and provide detailed input on grammar, punctuation, readability, clarity, leading statements, and general survey design. The feedback gathered was used to refine the survey before dissemination.

For this paper, the researchers selected three specific sections of the survey (i.e., Assumptions of Inferiority, Collaboration for IL Sessions, and Strides Towards Effective Collaboration) and looked for relationships between these sections and select demographic data (i.e. age, ethnicity/race, and gender). These three sections were selected for their relevance to statusbased microaggressions in the context of IL.

\section{Results}

In total, 557 individuals responded to the survey, out of whom $405(72.71 \%)$ progressed to the end of the survey. However, some participants chose to skip certain questions because all questions were optional. Making all questions optional had an impact on the total number of responses for individual questions. Responses from participants who did not proceed to the end of the survey but still answered select questions were also factored into the data analysis.

\section{Demographic Characteristics}

Figures 1 to 3 demonstrate the breakdown of survey participants by age, gender, and ethnicity/race. Out of 505 respondents who completed the question on age, there was a very small disparity, with most respondents selecting an age group between 26 and 64 . The smallest number of participants, $47(9.21 \%)$, selected the age group of either 22 to 25 or 65 and older. For age, the sample was not entirely representative of the overall target population (i.e., $A L$ in the U.S. and Canada). According to the American Library Association (ALA), librarians under the age of 35 make up the second smallest age demographic. Although this fact was not represented in our sample, the sample was in line with the ALA's data on the total number of librarians in the U.S. and Canada over the age of 65 . Out of 503 people who answered the question about gender identity, the majority of participants, $346(68.79 \%)$, identified as female. The significantly larger number of females is indicative of the overall target population of AL (ALA, 2018). As for ethnicity and/or race, an overwhelming number of participants, 374 (74.35\%), self-identified as white (non-Hispanic). As with gender, the significantly higher number of white participants was also representative of the target population as confirmed by the ALA's 2009-2010 American Community Survey Estimates (ALA, 2018). Overall, the researchers determined that the sample population largely mirrored the target population, providing the researchers with a representative sample. 


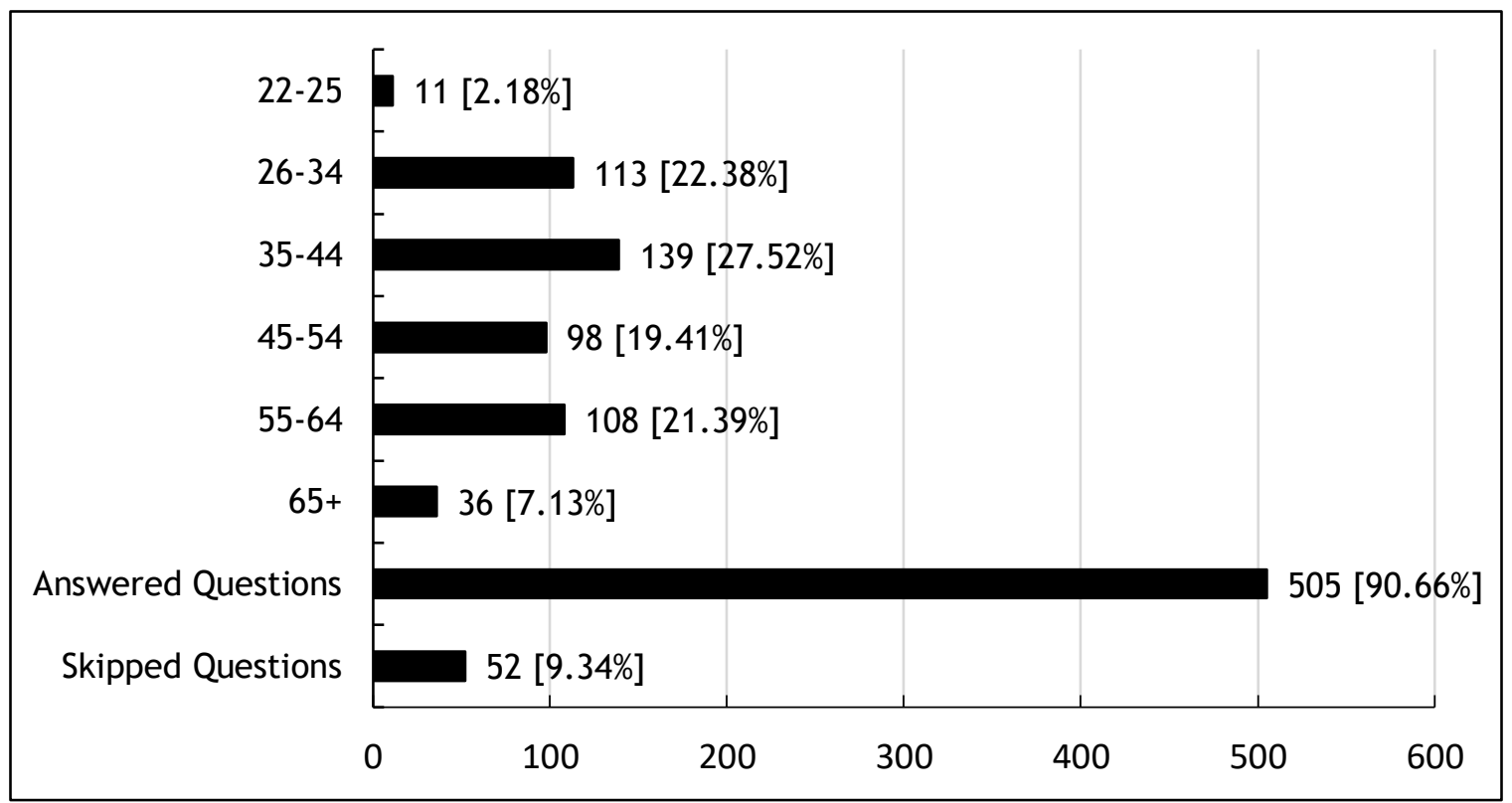

Figure 1. Age

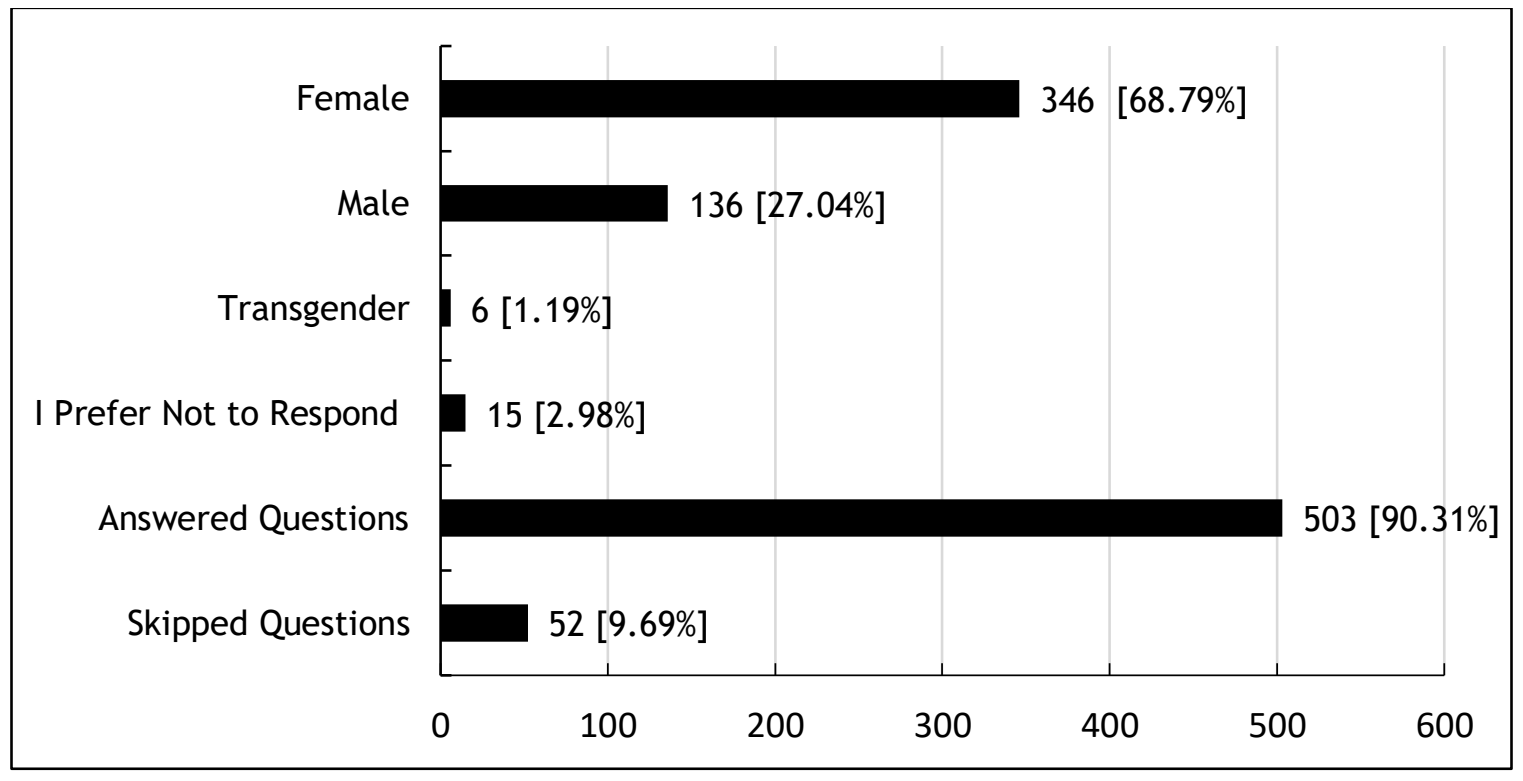

Figure 2. Gender 


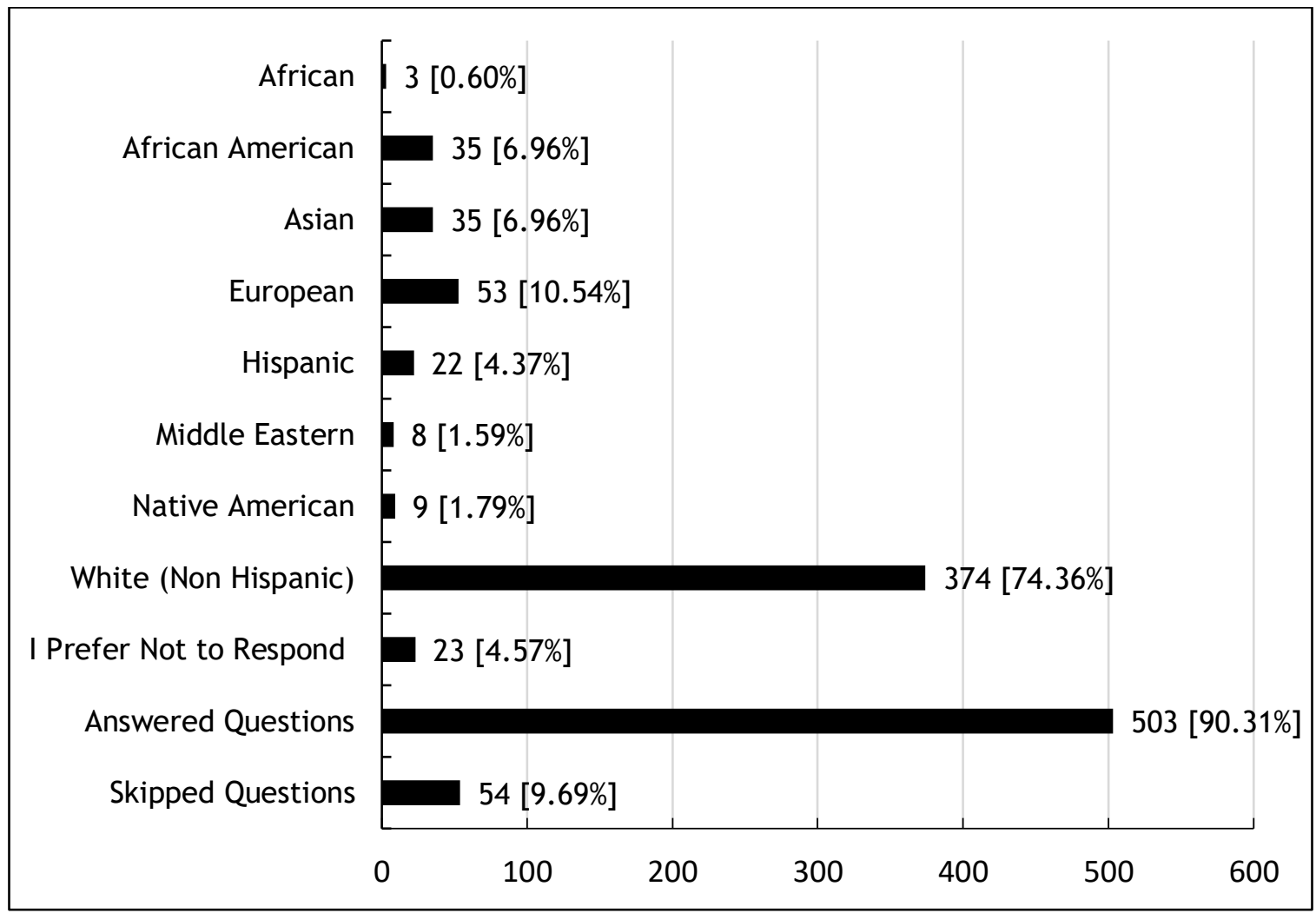

Figure 3. Ethnicity/Race

\section{Simple Linear Regression Analysis}

In determining if age, ethnicity, and gender contributed to perceived status-based microaggressions experienced by $\mathrm{AL}$, simple linear regression tests were conducted. A $\mathrm{p}$-value was used to determine if statistical significance existed for the questions in the three sections selected for analysis (i.e., Assumptions of Inferiority, Collaboration for IL Sessions, and Strides Towards Effective Collaboration). A large p-value at 0.05 or above indicated no statistical significance and therefore was not included in this paper. A p-value of less than 0.05 and closer to 0.00 demonstrated a marginal to strong statistical significance and is thus presented below.

\section{Age and microaggressions}

For age, the simple linear regression analysis revealed that four out of the 16 questions (from the three sections selected) were statistically significant. When TF made assumptions about ALs' level of education (Q15), statistical significance was identified between participants' ages and the TF's assumption that AL were not highly educated: $F(1,443)=4.839, \mathrm{p}<.028$, with an R2 of .011. When examining TF's comments regarding assumptions of intelligence and/or scholastic achievement (Q17), there was also a statistically significant relationship: $F(1,439)=$ 4.563, $\mathrm{p}<.033$, with an R2 of .013. A number of factors may be influencing why age plays a role in how TF view ALs' academic/scholastic achievement and level of education. It is possible 
that the younger age of some AL may further obscure TF's understanding of the academic requirements needed to become an AL. This theory may be supported by the fact that TF also have a difficult time distinguishing between library paraprofessionals/student employees and AL. The ability to make a distinction is further complicated by the fact that these staff members tend to be more visible in a library setting (Ivey, 1994).

When analyzing the question about TF providing $A L$ a syllabus of the course before library lectures (Q33), the researchers noticed a statistically significant relationship with age: $F$ $(1,404)=16.273, p<.000$, with an R2 of .039 . The researchers also observed a statistical significance: $F(1,404)=5.339, \mathrm{p}<.021$, with an $\mathrm{R} 2$ of .013 , when analyzing the question $(\mathrm{Q} 34)$ about TF asking AL to compress a library lecture into an unreasonable time. Here the statistical significance between age and both questions could be ascribed to the fact that TF may see younger $\mathrm{AL}$ as inexperienced and less likely to complain. Moreover, based on the Julien and Pecoskie (2009) suggestion, some AL may see IL instruction time as a "gift" provided by TF. This may be especially true for younger AL who lack the experience or ability to know when they are being treated unfairly or how to respectfully decline. Follow-up qualitative studies will do well to support, refute, or introduce fineness into this picture.

\section{Ethnicity/race and microaggressions}

In determining if ethnicity contributed to status-based microaggressions, the analysis determined that when TF started a conversation with AL using the language "no offense, but" (Q18), there was a statistical significance in AL perceiving the language as a form of statusbased microaggression: $F(1,444)=5.448, p<.02$, with an R2 of .012 . The remainder of the questions analyzed showed no statistical significance. Although the phrase "no offense, but" typically attempts to minimize the effect of any statement that follows, it is often a preface to a statement that is microaggressive or discriminatory. The use of the statement "no offense, but" may also be connected to race-based microaggressions (Sue, 2010). Therefore, it was not completely surprising to see a statistical significance between ethnicity and status-based microaggressive statements that begin with "no offense, but."

\section{Gender and microaggressions}

In determining if gender contributes to perceived status-based microaggressions experienced by $\mathrm{AL}$, the analysis revealed statistically significant results regarding TF's assumptions about ALs' scholastic or academic achievement $(\mathrm{Q} 15): F(1,442)=5.001, \mathrm{p}<.026$, with an R2 of .011 . The assumption made by TF about ALs' level of education may be impacted by the fact that females made up the largest portion of the sample population. The assumption may be furthered by biases that exist against women in an academic setting and/or the view of librarianship as a service-oriented profession.

When examining the question regarding TF asking $\mathrm{AL}$ to compress a library lecture into an unreasonable time $(\mathrm{Q} 34)$, there was a statistically significant relationship: $F(1,403)=5.135, \mathrm{p}$ $<.024$, with an R2 of .013. In determining if TF were providing AL a syllabus of the course before a library lecture (Q33), there also appeared to be a statistically significant relationship: $F(1,404)=4.507, \mathrm{p}<.034$, with an R2 of .011 . The statistical significance between gender and the TF failing to provide a syllabus and asking AL to compress a library lecture into an unreasonable timeframe could stem from the belief that AL of a specific gender are less likely to complain or protest. Although we do not know for certain if this applies more to females than males, further statistical analysis may provide in-depth insight into whether AL are indeed 
treated differently based on gender.

\section{Mean Analysis \\ Age and microaggressions}

In the mean analysis, age did not play a significant factor in AL reporting a higher rate of status-based microaggressions during collaborative efforts with TF (see Table 1). The mean for individuals under 44 , as opposed to those over 44 , was very similar. However, this was not the case when looking at the effect of age in the section entitled "Assumptions of Inferiority." In this section it was clear that individuals 45 and over consistently faced a higher rate of microaggressive behavior based on their perceived scholastic achievement, intelligence, academic status, and pay. This may be a result of TF viewing AL over a certain age as would-be academics or scholars who did not reach their full potential. The notion may be supported by the literature which states that TF are unsure about ALs' roles and the requirements needed to become an AL (Badke, 2005; Christiansen et al., 2004; Given \& Julien, 2005; Julien \& Given, 2003; Julien \& Pecoskie, 2009). However, further research is needed to determine if this is indeed the cause.

\section{Ethnicity/race and microaggressions}

When examining the mean for non-minority responses against the mean for minorities (see Table 2), it appears that minorities tend to experience higher rates of microaggressive behaviors. More specifically, the data indicates that minorities experience assumptions of inferiority at a higher rate than non-minorities. The only exceptions are in the area of scholastic achievement and pay. For non-minorities, the mean response was the highest when dealing with TF's assumptions about ALs' intelligence.

When it comes to collaboration in the context of IL, minorities do not fare as well as their nonminority counterparts. In all three sections of the survey (barring one question) the mean for minority responses exceeded the mean for non-minorities. This indicates that overall TF are not collaborating effectively with AL from minority groups in the context of IL. These results are concerning and may point to an underlying issue of race negatively impacting effective collaboration between TF and AL.

\section{Gender and microaggressions}

When comparing the mean responses for gender (see Table 3), males reported higher instances of microaggressive behavior by TF in all three sections analyzed. Moreover, the mean for male responses also exceeded the overall mean. This was unexpected, as the researchers had assumed the opposite would take place. It was hypothesized that sexism and gender discrimination may play a role in increasing the rate at which females experienced status-based microaggressions, but the data analysis proved that this was not the case. It must be noted, though, that a variety of factors may be influencing fewer reports of status-based microaggressions by females. One theory is that female AL may be more hesitant to report microaggressive behavior by TF due to a fear of retaliatory actions or a belief that they may find no support among colleagues or the library administration. Moreover, female librarians may avoid reporting such microaggressions due to social implications. Cheryl R. Kaiser and Carol T. Miller (2001) assert that victims of discrimination will avoid reporting acts of discrimination due to the social costs and negative evaluations that arise from such actions. A more accurate answer to this question warrants further research. 
Table 1. Mean Analysis - Age and Microaggression

\begin{tabular}{|c|c|c|c|c|}
\hline Question & Assumptions of Inferiority & $\begin{array}{l}\text { Overall } \\
\text { Mean } \\
\text { Response }\end{array}$ & $\begin{array}{l}20-44 \\
\text { Mean } \\
\text { Response }\end{array}$ & $\begin{array}{l}\text { 45-Up } \\
\text { Mean } \\
\text { Response }\end{array}$ \\
\hline 14 & $\begin{array}{l}\text { Teaching Faculty have assumed that I would not be as highly educated } \\
\text { because of my position or title. }\end{array}$ & 2.26 & 2.11 & 2.42 \\
\hline 15 & $\begin{array}{l}\text { Teaching Faculty have acted surprised at my scholastic or academic } \\
\text { achievements. }\end{array}$ & 2.25 & 2.09 & 2.43 \\
\hline 16 & $\begin{array}{l}\text { Teaching Faculty have assumed that I have a lower paying job because of my } \\
\text { position or title. }\end{array}$ & 2.59 & 2.57 & 2.62 \\
\hline 17 & $\begin{array}{l}\text { Teaching Faculty have told me I was "smart/intelligent" as though she/he } \\
\text { assumed I wouldn't be. }\end{array}$ & 3.22 & 3.07 & 3.38 \\
\hline 18 & $\begin{array}{l}\text { Teaching Faculty have started a conversation with the phrase "no offense, } \\
\text { but" and asked/mentioned something that could be perceived as a } \\
\text { microaggression? }\end{array}$ & 3.22 & 3.13 & 3.31 \\
\hline Question & Collaboration for IL Sessions & & & \\
\hline 27 & $\begin{array}{l}\text { Have Teaching Faculty ever asked you to teach a library session with no } \\
\text { notice? }\end{array}$ & 1.94 & 1.82 & 1.82 \\
\hline 28 & $\begin{array}{l}\text { Have Teaching Faculty ever failed to attend a prearranged library session for } \\
\text { their class or classes with notice? }\end{array}$ & 2.62 & 2.60 & 2.60 \\
\hline 29 & $\begin{array}{l}\text { Have Teaching Faculty ever failed to attend a prearranged library session for } \\
\text { their class without notice? }\end{array}$ & 3.09 & 3.07 & 3.07 \\
\hline
\end{tabular}

The International Journal of Information, Diversity, \& Inclusion, 2(3), 2018 ISSN 2574-3430, publish.lib.umd.edu/IJIDI/ 


\begin{tabular}{|c|c|c|c|c|}
\hline 30 & $\begin{array}{l}\text { Have Teaching Faculty ever asked you to teach a library session while they } \\
\text { are away on vacation? }\end{array}$ & 2.86 & 2.79 & 2.78 \\
\hline 31 & $\begin{array}{l}\text { Have Teaching Faculty ever asked you to teach a library session while they } \\
\text { are away at a conference? }\end{array}$ & 2.55 & 2.52 & 2.52 \\
\hline 32 & $\begin{array}{l}\text { Have Teaching Faculty ever demanded a library session on a specific day, } \\
\text { regardless of your schedule? }\end{array}$ & 2.92 & 2.78 & 2.78 \\
\hline 33 & $\begin{array}{l}\text { Have Teaching Faculty, when asked to do so, ever failed to provide you with } \\
\text { the class syllabus or additional information? }\end{array}$ & 2.64 & 2.39 & 2.39 \\
\hline 34 & $\begin{array}{l}\text { Have Teaching Faculty ever asked you to compress a library session into an } \\
\text { unreasonable time? }\end{array}$ & 2.42 & 2.22 & 2.22 \\
\hline 35 & $\begin{array}{l}\text { Have Teaching Faculty ever asked you to perform duties akin to those of a } \\
\text { Research Assistant? }\end{array}$ & 2.71 & 2.63 & 2.63 \\
\hline 36 & $\begin{array}{l}\text { Have Teaching Faculty ever failed to consult you when designing course } \\
\text { curriculum that involves library activities, assignments, etc.? }\end{array}$ & 1.67 & 1.54 & 1.54 \\
\hline Question & Strides Towards Effective Collaboration & & & \\
\hline 41 & Have Teaching Faculty ever actively involved you with their course design? & 3.67 & 3.65 & 3.65 \\
\hline
\end{tabular}


Table 2. Mean Analysis - Ethnicity/Race and Microaggressions

\begin{tabular}{|c|c|c|c|c|}
\hline Question & Assumptions of Inferiority & $\begin{array}{l}\text { Overall } \\
\text { Mean } \\
\text { Response }\end{array}$ & $\begin{array}{l}\text { Non- } \\
\text { Minority } \\
\text { Mean } \\
\text { Response }\end{array}$ & $\begin{array}{l}\text { Minority } \\
\text { Mean } \\
\text { Response }\end{array}$ \\
\hline 14 & $\begin{array}{l}\text { Teaching Faculty have assumed that I would not be as highly educated because of my } \\
\text { position or title. }\end{array}$ & 2.25 & 2.24 & 2.30 \\
\hline 15 & Teaching Faculty have acted surprised at my scholastic or academic achievements. & 2.26 & 2.25 & 2.30 \\
\hline 16 & $\begin{array}{l}\text { Teaching Faculty have assumed that I have a lower paying job because of my position } \\
\text { or title. }\end{array}$ & 2.59 & 2.56 & 2.64 \\
\hline 17 & $\begin{array}{l}\text { Teaching Faculty have told me I was "smart/intelligent" as though she/he assumed I } \\
\text { wouldn't be. }\end{array}$ & 3.22 & 3.26 & 3.12 \\
\hline 18 & $\begin{array}{l}\text { Teaching Faculty have started a conversation with the phrase "no offense, but" and } \\
\text { asked/mentioned something that could be perceived as a microaggression? }\end{array}$ & 3.22 & 3.27 & 3.09 \\
\hline Question & Collaboration for IL Sessions & & & \\
\hline 27 & Have Teaching Faculty ever asked you to teach a library session with no notice? & 1.93 & 1.93 & 1.96 \\
\hline 28 & $\begin{array}{l}\text { Have Teaching Faculty ever failed to attend a prearranged library session for their class } \\
\text { or classes with notice? }\end{array}$ & 2.61 & 2.62 & 2.58 \\
\hline 29 & $\begin{array}{l}\text { Have Teaching Faculty ever failed to attend a prearranged library session for their class } \\
\text { without notice? }\end{array}$ & 3.08 & 3.06 & 3.14 \\
\hline
\end{tabular}

The International Journal of Information, Diversity, \& Inclusion, 2(3), 2018 ISSN 2574-3430, publish.lib.umd.edu/IJIDI/ 
Have Teaching Faculty ever asked you to teach a library session while they are away on vacation?

2.85

Have Teaching Faculty ever asked you to teach a library session while they are away at a conference?

Have Teaching Faculty ever demanded a library session on a specific day, regardless of your schedule?

Have Teaching Faculty, when asked to do so, ever failed to provide you with the class syllabus or additional information?

Have Teaching Faculty ever asked you to compress a library session into an unreasonable time?

Have Teaching Faculty ever asked you to perform duties akin to those of a Research Assistant?

Have Teaching Faculty ever failed to consult you when designing course curriculum that involves library activities, assignments, etc.?
2.54

2.62

2.63

2.57

2.42

2.37

2.56

2.70

2.64

2.88

1.65

1.63

1.70

\section{Question Strides Towards Effective Collaboration}


Table 3. Mean Analysis - Gender and Microaggressions

\begin{tabular}{|c|c|c|c|c|}
\hline Question & Assumptions of Inferiority & $\begin{array}{l}\text { Overall } \\
\text { Mean } \\
\text { Response }\end{array}$ & $\begin{array}{l}\text { Male } \\
\text { Mean } \\
\text { Response }\end{array}$ & $\begin{array}{l}\text { Female } \\
\text { Mean } \\
\text { Response }\end{array}$ \\
\hline 14 & $\begin{array}{l}\text { Teaching Faculty have assumed that I would not be as highly educated because of } \\
\text { my position or title. }\end{array}$ & 2.27 & 2.58 & 2.14 \\
\hline 15 & Teaching Faculty have acted surprised at my scholastic or academic achievements. & 2.26 & 2.53 & 2.14 \\
\hline 16 & $\begin{array}{l}\text { Teaching Faculty have assumed that I have a lower paying job because of my } \\
\text { position or title. }\end{array}$ & 2.60 & 2.69 & 2.55 \\
\hline 17 & $\begin{array}{l}\text { Teaching Faculty have told me I was "smart/intelligent" as though she/he assumed } \\
\text { I wouldn't be. }\end{array}$ & 3.22 & 3.30 & 3.20 \\
\hline 18 & $\begin{array}{l}\text { Teaching Faculty have started a conversation with the phrase "no offense, but" } \\
\text { and asked/mentioned something that could be perceived as a microaggression? }\end{array}$ & 3.22 & 3.22 & 3.23 \\
\hline Question & Collaboration for IL Sessions & & & \\
\hline 27 & Have Teaching Faculty ever asked you to teach a library session with no notice? & 1.94 & 2.23 & 1.81 \\
\hline 28 & $\begin{array}{l}\text { Have Teaching Faculty ever failed to attend a prearranged library session for their } \\
\text { class or classes with notice? }\end{array}$ & 2.62 & 2.72 & 2.57 \\
\hline 29 & $\begin{array}{l}\text { Have Teaching Faculty ever failed to attend a prearranged library session for their } \\
\text { class without notice? }\end{array}$ & 3.09 & 3.25 & 3.03 \\
\hline
\end{tabular}

The International Journal of Information, Diversity, \& Inclusion, 2(3), 2018 ISSN 2574-3430, publish.lib.umd.edu/IJIDI/ 


\begin{tabular}{|c|c|c|c|c|}
\hline 30 & $\begin{array}{l}\text { Have Teaching Faculty ever asked you to teach a library session while they are } \\
\text { away on vacation? }\end{array}$ & 2.86 & 3.01 & 2.78 \\
\hline 31 & $\begin{array}{l}\text { Have Teaching Faculty ever asked you to teach a library session while they are } \\
\text { away at a conference? }\end{array}$ & 2.55 & 2.71 & 2.46 \\
\hline 32 & $\begin{array}{l}\text { Have Teaching Faculty ever demanded a library session on a specific day, } \\
\text { regardless of your schedule? }\end{array}$ & 2.92 & 3.12 & 2.82 \\
\hline 33 & $\begin{array}{l}\text { Have Teaching Faculty, when asked to do so, ever failed to provide you with the } \\
\text { class syllabus or additional information? }\end{array}$ & 2.64 & 3.00 & 2.49 \\
\hline 34 & $\begin{array}{l}\text { Have Teaching Faculty ever asked you to compress a library session into an } \\
\text { unreasonable time? }\end{array}$ & 2.42 & 2.72 & 2.31 \\
\hline 35 & $\begin{array}{l}\text { Have Teaching Faculty ever asked you to perform duties akin to those of a } \\
\text { Research Assistant? }\end{array}$ & 2.71 & 2.87 & 2.62 \\
\hline 36 & $\begin{array}{l}\text { Have Teaching Faculty ever failed to consult you when designing course curriculum } \\
\text { that involves library activities, assignments, etc.? }\end{array}$ & 1.67 & 1.90 & 1.58 \\
\hline Question & Strides Towards Effective Collaboration & & & \\
\hline 41 & Have Teaching Faculty ever actively involved you with their course design? & 3.67 & 3.83 & 3.60 \\
\hline
\end{tabular}




\section{Rate of Response Analysis}

\section{Assumptions of inferiority}

The breakdown of responses was supportive of the notion found in the literature that some TF view $\mathrm{AL}$ as subordinate. In the section entitled Assumptions of Inferiority (Q14 to Q18) the questions were specifically designed to gauge whether TF view AL as inferior based on their status in academia. For questions 14,15 and 16 the researchers observed that the rates of response for having "Very Frequently," "Frequently," and "Occasionally" experienced an assumption of inferiority either nearly equaled or in many cases exceeded the number of responses for "Rarely" or "Never" (see Table 4).

\section{Collaboration for information literacy sessions}

On the topic of effective collaboration for IL, it was evident that for nearly every question barring question 29, the rate of response for having "Very Frequently," "Frequently," and "Occasionally" encountered a negative experience either nearly equaled or in many cases exceeded the number of responses for "Rarely" or "Never." This supports the claims made in the LIS literature about the often ineffective collaboration that exists between TF and AL. The data indicates that TF have the propensity for making either unrealistic or unreasonable demands of $\mathrm{AL}$ when collaborating on IL sessions. Examples of these demands can include having AL compress a library session into an unrealistic time, not providing a syllabus, and asking AL to teach a library session while on vacation or at a conference. These types of demands can be viewed as microaggressive in an academic environment where collegiality is encouraged between TF and AL. Moreover, it may indicate a lack of understanding of the roles of $A L$ and a reluctance to view $A L$ as equals (see Table 5).

\section{Strides toward effective collaboration}

For this section of the survey, the researchers only focused on question 41 , due to its relevance to the topic of IL collaboration in course design. It is apparent from the higher rate of response for "Occasionally," "Rarely," and "Never" combined that AL play a minor role in collaborating with TF. Multiple reasons could explain this occurrence, including the lack of understanding of the role of $\mathrm{AL}$ or how AL could assist TF on integrating IL into a course (see Table 6).

\section{Discussion}

The data analysis supported the assertion that many TF view AL as subordinate. It is very likely that this perception has an impact on the way in which TF behave with $\mathrm{AL}$ in IL instruction and collaboration. Indeed, in the survey, AL overwhelmingly reported ineffective collaborative efforts when working with TF. Moreover, the data also revealed that TF fail to initiate collaborative partnerships with AL when designing their courses, which may be symptomatic of TF's ignorance of the role of AL in academia and may result in increased instances of statusbased microaggressions. Moreover, the data revealed that AL were subjected to status-based microaggressions, often expressed in ways that were unique to the field of academic librarianship. For example, many AL reported that TF have little regard for their academic and scholastic achievement and may make a variety of unreasonable demands of AL based on this lack of knowledge. These results support the conclusions found in the literature, which assert that TF may see AL as subordinates who play a largely service-oriented role in academia. 
Table 4. Rate of Response Analysis - Assumptions of Inferiority

\begin{tabular}{|c|c|c|c|c|c|c|c|}
\hline Question & Assumptions of Inferiority & $\begin{array}{l}\text { Rate of } \\
\text { Response }\end{array}$ & $\begin{array}{l}\text { Very } \\
\text { Frequently }\end{array}$ & Frequently & Occasionally & Rarely & Never \\
\hline 14 & $\begin{array}{l}\text { Teaching Faculty have assumed that I would } \\
\text { not be as highly educated because of my } \\
\text { position or title. }\end{array}$ & $\begin{array}{l}79.89 \% \\
(445)\end{array}$ & $8.76 \%(39)$ & $14.38 \%(64)$ & $35.96 \%(160)$ & $\begin{array}{l}23.82 \% \\
(106)\end{array}$ & $\begin{array}{l}17.08 \% \\
(76)\end{array}$ \\
\hline 15 & $\begin{array}{l}\text { Teaching Faculty have acted surprised at my } \\
\text { scholastic or academic achievement. }\end{array}$ & $\begin{array}{l}80.43 \% \\
(448)\end{array}$ & $9.38 \%(42)$ & $17.86 \%(80)$ & $31.47 \%(141)$ & $\begin{array}{l}20.54 \% \\
(92)\end{array}$ & $\begin{array}{l}20.76 \% \\
(93)\end{array}$ \\
\hline 16 & $\begin{array}{l}\text { Teaching Faculty have assumed that I have a } \\
\text { lower paying job because of my position or } \\
\text { title. }\end{array}$ & $\begin{array}{l}76.48 \% \\
(426)\end{array}$ & $5.40 \%(23)$ & $16.90 \%(72)$ & $24.41 \%(104)$ & $\begin{array}{l}19.72 \% \\
(84)\end{array}$ & $\begin{array}{l}33.57 \% \\
(143)\end{array}$ \\
\hline 17 & $\begin{array}{l}\text { Teaching Faculty have told me I was } \\
\text { "smart/intelligent" as though she/he assumed I } \\
\text { wouldn't be. }\end{array}$ & $\begin{array}{l}79.17 \% \\
(441)\end{array}$ & $2.49 \%(11)$ & $7.48 \%(33)$ & $14.96 \%(66)$ & $\begin{array}{l}15.42 \% \\
(68)\end{array}$ & $\begin{array}{l}59.64 \% \\
(263)\end{array}$ \\
\hline 18 & $\begin{array}{l}\text { Teaching Faculty have started a conversation } \\
\text { with the phrase "no offense, but" and } \\
\text { asked/mentioned something that could be } \\
\text { perceived as a microaggression? }\end{array}$ & $\begin{array}{l}80.25 \% \\
(447)\end{array}$ & $3.58 \%(16)$ & $2.91 \%(13)$ & $15.44 \%(69)$ & $\begin{array}{l}23.94 \% \\
(107)\end{array}$ & $\begin{array}{l}54.14 \% \\
(242)\end{array}$ \\
\hline
\end{tabular}


Table 5. Rate of Response Analysis - Collaboration for Information Literacy Sessions

\begin{tabular}{|c|c|c|c|c|c|c|c|}
\hline Question & Collaboration for IL Sessions & $\begin{array}{l}\text { Rate of } \\
\text { Response }\end{array}$ & $\begin{array}{l}\text { Very } \\
\text { Frequently }\end{array}$ & Frequently & Occasionally & Rarely & Never \\
\hline 27 & $\begin{array}{l}\text { Have Teaching Faculty ever asked you to } \\
\text { teach a library session with no notice? }\end{array}$ & $\begin{array}{l}73.43 \% \\
(409)\end{array}$ & $\begin{array}{l}10.27 \% \\
(42)\end{array}$ & $\begin{array}{l}21.27 \% \\
(87)\end{array}$ & $42.79 \%(175)$ & $\begin{array}{l}15.65 \% \\
(64)\end{array}$ & $\begin{array}{l}10.02 \% \\
(41)\end{array}$ \\
\hline 28 & $\begin{array}{l}\text { Have Teaching Faculty ever failed to attend a } \\
\text { prearranged library session for their class or } \\
\text { classes with notice? }\end{array}$ & $\begin{array}{l}73.25 \% \\
(408)\end{array}$ & $1.23 \%(5)$ & $7.60 \%(31)$ & $41.67 \%(170)$ & $\begin{array}{l}26.95 \% \\
(110)\end{array}$ & $\begin{array}{l}22.55 \% \\
(92)\end{array}$ \\
\hline 29 & $\begin{array}{l}\text { Have Teaching Faculty ever failed to attend a } \\
\text { prearranged library session for their class } \\
\text { without notice? }\end{array}$ & $\begin{array}{l}72.89 \% \\
(406)\end{array}$ & $1.48 \%(6)$ & $1.97 \%(8)$ & $24.63 \%(100)$ & $\begin{array}{l}29.56 \% \\
(120)\end{array}$ & $\begin{array}{l}42.36 \% \\
(172)\end{array}$ \\
\hline 30 & $\begin{array}{l}\text { Have Teaching Faculty ever asked you to } \\
\text { teach a library session while they are away } \\
\text { on vacation? }\end{array}$ & $\begin{array}{l}72.17 \% \\
(402)\end{array}$ & $2.99 \%(12)$ & $7.21 \%(29)$ & $31.34 \%(126)$ & $\begin{array}{l}17.41 \% \\
(70)\end{array}$ & $\begin{array}{l}41.04 \% \\
(165)\end{array}$ \\
\hline 31 & $\begin{array}{l}\text { Have Teaching Faculty ever asked you to } \\
\text { teach a library session while they are away at } \\
\text { a conference? }\end{array}$ & $\begin{array}{l}72.53 \% \\
(404)\end{array}$ & $4.21 \%(17)$ & $9.41 \%(17)$ & $39.85 \%(161)$ & $\begin{array}{l}20.54 \% \\
(83)\end{array}$ & $\begin{array}{l}25.99 \% \\
(105)\end{array}$ \\
\hline 32 & $\begin{array}{l}\text { Have Teaching Faculty ever demanded a } \\
\text { library session on a specific day, regardless of } \\
\text { your schedule? }\end{array}$ & $\begin{array}{l}72.89 \% \\
(406)\end{array}$ & $2.46 \%(10)$ & $9.61 \%(39)$ & $23.40 \%(95)$ & $\begin{array}{l}22.66 \% \\
(92)\end{array}$ & $\begin{array}{l}41.87 \% \\
(170)\end{array}$ \\
\hline
\end{tabular}

The International Journal of Information, Diversity, \& Inclusion, 2(3), 2018 ISSN 2574-3430, publish.lib.umd.edu/IJIDI/ 


\begin{tabular}{|c|c|c|c|c|c|c|c|}
\hline 33 & $\begin{array}{l}\text { Have Teaching Faculty, when asked to do so, } \\
\text { ever failed to provide you with the syllabus } \\
\text { or additional information? }\end{array}$ & $\begin{array}{l}73.07 \% \\
(407)\end{array}$ & $5.16 \%(21)$ & $\begin{array}{l}11.55 \% \\
(47)\end{array}$ & $27.27 \%(111)$ & $\begin{array}{l}26.29 \% \\
(107)\end{array}$ & $\begin{array}{l}29.73 \% \\
(121)\end{array}$ \\
\hline 34 & $\begin{array}{l}\text { Have Teaching Faculty ever asked you to } \\
\text { compress a library session into an } \\
\text { unreasonable time? }\end{array}$ & $\begin{array}{l}72.89 \% \\
(406)\end{array}$ & $8.37 \%(34)$ & $\begin{array}{l}12.07 \% \\
(49)\end{array}$ & $33.00 \%(134)$ & $\begin{array}{l}22.66 \% \\
(92)\end{array}$ & $\begin{array}{l}23.89 \% \\
(97)\end{array}$ \\
\hline 35 & $\begin{array}{l}\text { Have Teaching Faculty ever asked you to } \\
\text { perform duties akin to those of a Research } \\
\text { Assistant? }\end{array}$ & $\begin{array}{l}73.61 \% \\
(410)\end{array}$ & $4.15 \%(17)$ & $7.32 \%(30)$ & $32.44 \%$ (133) & $\begin{array}{l}26.10 \% \\
(107)\end{array}$ & $\begin{array}{l}30.00 \% \\
(123)\end{array}$ \\
\hline 36 & $\begin{array}{l}\text { Have Teaching Faculty ever failed to consult } \\
\text { you with designing course curriculum that } \\
\text { involves library activities, assignments, etc.? }\end{array}$ & $\begin{array}{l}72.35 \% \\
(403)\end{array}$ & $\begin{array}{l}22.33 \% \\
(90)\end{array}$ & $\begin{array}{l}27.05 \% \\
(106)\end{array}$ & $26.80 \%(108)$ & $\begin{array}{l}11.66 \% \\
(47)\end{array}$ & $\begin{array}{l}12.16 \% \\
(49)\end{array}$ \\
\hline
\end{tabular}

Table 6. Rate of Response Analysis - Strides Toward Effective Collaboration

\begin{tabular}{|c|c|c|c|c|c|c|c|}
\hline Question & Strides Towards Effective Collaboration & $\begin{array}{l}\text { Rate of } \\
\text { Response }\end{array}$ & $\begin{array}{l}\text { Very } \\
\text { Frequently }\end{array}$ & Frequently & Occasionally & Rarely & Never \\
\hline 41 & $\begin{array}{l}\text { Have Teaching Faculty ever actively involved } \\
\text { you with their course design? }\end{array}$ & $\begin{array}{l}71.27 \% \\
(397)\end{array}$ & $00.76 \%(3)$ & $6.05 \%(24)$ & $34.76 \%(138)$ & $\begin{array}{l}33.00 \% \\
(131)\end{array}$ & $\begin{array}{l}24.44 \% \\
(101)\end{array}$ \\
\hline
\end{tabular}

The International Journal of Information, Diversity, \& Inclusion, 2(3), 2018 ISSN 2574-3430, publish.lib.umd.edu/IJIDI/ 
The survey analysis also sought to determine whether AL face increased instances of statusbased microaggressions based on self-reported demographic information. The data indicates that there is a relationship between demographic characteristics of $A L$ and the types of statusbased microaggressions they may encounter. In some cases, these relationships constituted statistically significant correlations.

The data also revealed a relationship between age and the assumption by TF that AL were not highly educated. One factor that may influence such an assumption is the inability of TF to determine the difference between the various employees and their roles within an academic library. TF may wrongly assume that younger AL are library paraprofessionals and therefore make assumptions about the AL's level of education. In addition, the data showed that TF also make unrealistic demands of AL based on age. This phenomenon may be connected to the fact that TF view younger, more inexperienced $\mathrm{AL}$ as less likely to complain about uncollegial behavior. However, it is noteworthy that AL over the age of 44 faced a different type of statusbased microaggression. These AL complained about the fact that TF often saw them as inferior based on their scholastic achievement, intelligence, academic status, and pay. It is interesting to note that AL are facing different types of status-based microaggressions based on their age and level of experience. Unfortunately, the increased experience that may come with age does not seem to reduce the likelihood of experiencing some form of status-based microaggression.

The data analysis on the role of ethnicity and race provided the researchers with an interesting representation of how race plays a role in status-based microaggressions. The data revealed that the statement "no offense, but," which is often used in the context of racial microaggressions, was also used by TF when interacting with $\mathrm{AL}$ in the context of IL instruction. Although the focus of the study was the topic of status, the data analysis illustrated that race plays a role in the interactions between TF and AL. It quickly became apparent that race continues to have an impact on status-based microaggressions. TF viewed AL from minority groups as different and treated them as such. This was clear from the fact that AL who identified as minorities experienced assumptions of inferiority at a higher rate and collaborated much less effectively with TF. This presents a reason for concern, as the LIS literature has demonstrated that racial and ethnic diversity is a real issue in the field of librarianship. However, more information is needed on what roles diversity and ethnicity play in the relationship between TF and AL. This type of information could help identify the hurdles that may exist in developing effective collaboration between the two groups.

The gender analysis shows that TF may act differently with AL based on the AL's gender identity. The data revealed that some TF perceived $\mathrm{AL}$ as less educated and tended to make more unrealistic demands of these AL based on their gender. This observation is problematic and is likely connected to a variety of gender stereotypes and biases, which we did not investigate in-depth in this study. Although the data did not confirm that female AL experienced increased status-based microaggressions, this finding could be a function of several factors. The researchers had to take into account the fact that the majority of the sample was female and that women generally tend to experience greater gender discrimination in the workplace; at the same time, female employees are less likely to report incidents to superiors. Male AL reported higher instances of status-based microaggressions, which could be related to the fact that male employees are more forthcoming about this type of incident. Further research to corroborate these possible connections is very much needed.

It is important to note that although this study provides some indications of how status-based microaggressions may change over time, these microaggressions are heavily influenced by 
context. While $\mathrm{AL}$ indicated their experiences with status-based microaggressions at a given point in time, their in-the-moment experiences with microaggressive behaviors will evolve as their age, level of education, and years of experience change. For some participants, this may mean that exposure to status-based microaggressive behaviors may increase or diminish over time.

\section{Limitations}

The researchers acknowledge that there were limitations to the survey and the study as a whole. First, the survey was only sent to three Canadian-based electronic mailing lists, which could limit the pool of Canadian participants. Second, the project was influenced by the researchers' personal experiences regarding the existence of status-based microaggressive behavior from TF toward AL. These experiences served merely as the impetus to conduct a quantitative study to determine if the researchers' perceptions were justified. To mitigate the influence of bias on the development of the survey, the researchers initiated a pretest. Third, this study was impacted by the lack of literature on microaggressions that occur in academic libraries. As a result, the researchers did not have a significant body of research to draw upon when developing questions to be included in the survey. Moreover, unlike microaggressions based on race, gender, or sexual orientation, it proved more difficult to identify what constitutes a status-based microaggression between TF and AL. As no previous research exists on the topic in academic libraries, we could not assume that AL would automatically know what actions from a TF would constitute a status-based microaggression. Therefore, the researchers developed a series of questions based on situations in which status-based microaggressive behavior may occur between TF and AL. Fourth, it is important to note that participants were self-reporting instances of microaggression based on their personal experiences and perceptions. Fifth, the researchers were unable to compare their results with previous studies to ensure validity. Finally, the inherent weaknesses of using a Likert scale also proved challenging, with the majority of participants selecting the neutral option for most questions. Although participants in our survey remained anonymous, studies using Likert scales have shown that the majority of participants may gravitate toward the neutral option in response to survey questions in a phenomenon known as "satisficing." This typically occurs when survey participants attempt to avoid the implications involved with selecting an extreme choice, even if the extreme choice is most accurate (Krosnick, Narayan, \& Smith, 1996). Conversely, participants may have selected the neutral option in an attempt to simply choose an answer quickly (Krosnick et al.,1996).

\section{Conclusion}

This research paper represents a foray into the topic of status-based microaggressions within academia and between TF and AL. While some work has been done on microaggressions in higher education, the presented research fills the gap in quantitative data that exists on status-based microaggressions. The results of the survey analysis demonstrate that status-based microaggressions, although not pervasive, do exist. Moreover, the data indicated that many AL experience more frequent instances of status-based microaggressions from TF based on reported demographic characteristics. A variety of factors may be influencing why AL with specific demographic characteristics encounter more status-based microaggressions than others, including stereotypes, biases, and an ingrained view of librarianship as a serviceoriented profession or subordinate role.

The International Journal of Information, Diversity, \& Inclusion, 2(3), 2018

ISSN 2574-3430, publish.lib.umd.edu/IJIDI/ 
The field of LIS would benefit from future studies that use the concept of microaggression to examine the experiences of AL collaborating with TF. Such research could play a vital role in promoting collegiality and fruitful collaboration between these groups. Without a more thorough understanding of how status-based microaggressions impact this relationship, it will be difficult to bridge the gap that exists between TF and AL.

\section{Appendix}

\section{Survey Questions}

\section{Assessing Perceived Teaching Faculty Microaggressions Towards Academic Librarians Survey}

\section{Personal Demographics}

1. Please tell us your age.
$22-25$
$26-34$
$35-44$
$45-54$
$55-64$
65 or Older

2. What is your gender identity (check all that apply)?
Female
Male
Transgender
I Prefer Not to Respond
Other (Please Identify):

3. With which ethnicity and/or racial group do you identify (check all that apply)?

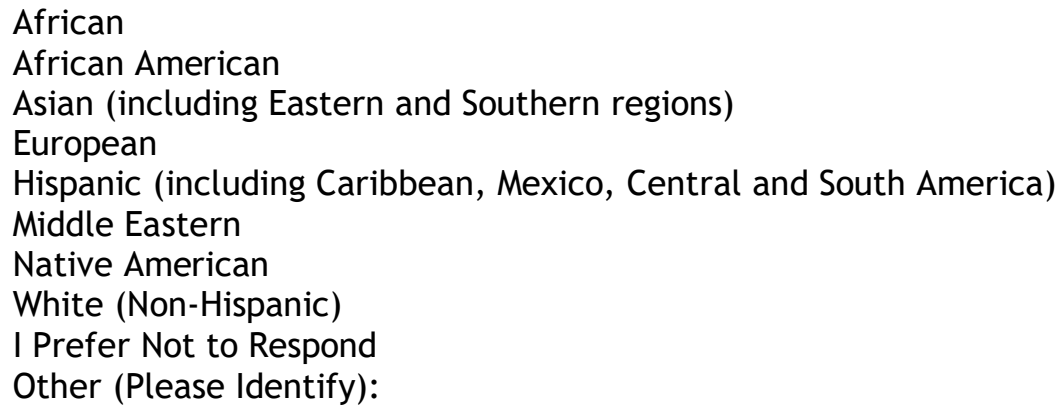

4. I am a (check all that apply):

\section{U.S. Citizen}


Canadian Citizen

U.S. Permanent Resident

Canadian Permanent Resident

Other (Please Identify):

5. In which state or province do you primarily reside?

\section{Professional Demographics}

6. How many years have you been an Academic Librarian (round up)?

7. What is your personnel classification?

Academic Staff

Adjunct Faculty

Tenured Faculty

Other (Please Identify):

8. At which type of academic institution do you work?

Associate's College

Baccalaureate College

Master's College or University

Research University

Special focus institution (e.g., culinary institute)

Tribal College

Other (Please Identify):

9. How many years have you worked at your current institution?

\section{Microaggressions in a Larger Context}

10. Are you familiar with the theory of microaggression (if not skip to question 13)?

Yes

No

Somewhat

11. Microaggressions are a perceived notion or a figment of one's imagination.

Strongly Agree

Agree

Neutral

Disagree

Strongly Disagree

Other (Please Specify):

12. Microaggressions are larger than race or gender issues.

Strongly Agree

Agree 
Neutral

Disagree

Strongly Disagree

13. Have the Library Administrators at your institution provided formal or informal training on how to interact and collaborate with Teaching Faculty?

Very Frequently

Frequently

Occasionally

Rarely

Never

\section{Assumptions of Inferiority}

14. Teaching Faculty have assumed that I would not be as highly educated because of my position or title.

Very Frequently

Frequently

Occasionally

Rarely

Never

15. Teaching Faculty have acted surprised at my scholastic or academic achievements.

Very Frequently

Frequently

Occasionally

Rarely

Never

16. Teaching Faculty have assumed that I had a lower paying job because of my position or title.

Very Frequently

Frequently

Occasionally

Rarely

Never

17. Teaching Faculty have told me I was 'smart/intelligent' as though she/he assumed I wouldn't be.

Very Frequently
Frequently
Occasionally
Rarely
Never

18. Teaching Faculty have started a conversation with the phrase 'no offense, but' and

The International Journal of Information, Diversity, \& Inclusion, 2(3), 2018 
asked/mentioned something that could be perceived as a microaggression.

Very Frequently

Frequently

Occasionally

Rarely

Never

Classism

19. Have Teaching Faculty ever stated that 'there is a difference between the two of us' in terms of value to the institution?

Very Frequently

Frequently

Occasionally

Rarely

Never

20. Have Teaching Faculty ever stated that all Librarians face the same obstacles when dealing with Teaching Faculty?

Very Frequently

Frequently

Occasionally

Rarely

Never

21. Have Teaching Faculty ever stated that I should not complain about negative treatment by Teaching Faculty?

Very Frequently

Frequently

Occasionally

Rarely

Never

22. Have Library Administrators ever stated that there is a difference between Teaching Faculty and Academic Librarians in terms of value to the institution?

Very Frequently

Frequently

Occasionally

Rarely

Never

23. Have Library Administrators ever stated that I should not complain about negative treatment by Teaching Faculty?

Very Frequently

Frequently

The International Journal of Information, Diversity, \& Inclusion, 2(3), 2018 
Occasionally

Rarely

Never

24. Have Library Administrators ever stated that all Academic Librarians face the same obstacles when dealing with Teaching Faculty?

Very Frequently

Frequently

Occasionally

Rarely

Never

25. Have library colleagues ever stated that I should not complain about negative treatment by Teaching Faculty?

Very Frequently

Frequently

Occasionally

Rarely

Never

26. Have library colleagues ever stated that all Librarians face the same obstacles when dealing with Teaching Faculty?

Very Frequently

Frequently

Occasionally

Rarely

Never

\section{Collaboration for IL Sessions}

27. Have Teaching Faculty ever asked you to teach a library session with little to no notice?

Very Frequently

Frequently

Occasionally

Rarely

Never

28. Have Teaching Faculty ever failed to attend a prearranged library session for their class or classes with notice?

Very Frequently

Frequently

Occasionally

Rarely

Never

29. Have Teaching Faculty ever failed to attend a prearranged library session for their class

The International Journal of Information, Diversity, \& Inclusion, 2(3), 2018 
or classes without notice?

Very Frequently

Frequently

Occasionally

Rarely

Never

30. Have Teaching Faculty ever asked you to teach a library session while they are away on vacation?

Very Frequently

Frequently

Occasionally

Rarely

Never

31. Have Teaching Faculty ever asked you to teach a library session while they are away at a conference?

Very Frequently

Frequently

Occasionally

Rarely

Never

32. Have Teaching Faculty ever demanded a library session on a specific day, regardless of your schedule?

Very Frequently

Frequently

Occasionally

Rarely

Never

33. Have Teaching Faculty, when asked to do so, ever failed to provide you with the class syllabus or additional information?

Very Frequently

Frequently

Occasionally

Rarely

Never

34. Have Teaching Faculty ever asked you to compress a library session to an unreasonable time?

Very Frequently

Frequently

Occasionally

Rarely

The International Journal of Information, Diversity, \& Inclusion, 2(3), 2018 
Never

35. Have Teaching Faculty ever asked you to perform duties akin to those of a Research Assistant?

Very Frequently

Frequently

Occasionally

Rarely

Never

36. Have Teaching Faculty ever failed to consult you when designing course curriculum that involves library activities, assignments etc.?

\author{
Very Frequently \\ Frequently \\ Occasionally \\ Rarely \\ Never
}

\title{
Collaboration for Technical Services
}

37. Have Teaching Faculty ever treated you solely like a service point?

\author{
Very Frequently \\ Frequently \\ Occasionally \\ Rarely \\ Never
}

38. Have Teaching Faculty ever asked you to acquire materials at the last minute (e.g., course reserves)?
Very Frequently
Frequently
Occasionally
Rarely
Never

39. Have Teaching Faculty ever demanded resources or materials even after being told the item/s cannot be purchased?

Very Frequently

Frequently

Occasionally

Rarely

Never

\section{Strides Towards Effective Collaboration}

40. Have Teaching Faculty ever consistently submitted item requests (e.g., course 
reserves) in a timely manner?

Very Frequently

Frequently

Occasionally

Rarely

Never

41. Have Teaching Faculty ever actively involved you with their course design?

Very Frequently

Frequently

Occasionally

Rarely

Never

42. Have Teaching Faculty ever involved you or your colleagues in grant proposals that have a library component?

Very Frequently

Frequently

Occasionally

Rarely

Never

43. If appropriate, have Teaching Faculty ever involved you in digital projects (e.g., digital humanities) for which the library is a stakeholder?

Very Frequently

Frequently

Occasionally

Rarely

Never

\section{References}

Alabi, J. (2015). Racial microaggressions in academic libraries: Results of a survey of minority and non-minority librarians. The Journal of Academic Librarianship, 41(1), 47-53.

American Library Association. (2018). Diversity counts. Retrieved from http: //www.ala.org/aboutala/offices/diversity/diversitycounts/divcounts

Badke, W. B. (2005). Can't get no respect: Helping faculty to understand the educational power of information literacy. The Reference Librarian, 43(89/90), 63-80.

Budd, J. M. (2005). The changing academic library. Chicago, IL: American Library Association.

Christiansen, L., Stombler, M., \& Thaxton, L. (2004). A report on librarian-faculty relations from a sociological perspective. The Journal of Academic Librarianship, 30(2), 116-121. 
Delaney, G., \& Bates, J. (2015). Envisioning the academic library: A reflection on roles, relevancy and relationships. New Review of Academic Librarianship, 21(1), 30-51.

Gaertner, S. L., \& Dovidio, J. F. (1986). The aversive form of racism. In J. F. Dovidio. \& S. L. Gaertner (Eds.), Prejudice, discrimination, and racism, (pp. 61-89). Orlando, FL: Academic Press.

Given, L. M., \& Julien, H. (2005). Finding common ground: An analysis of librarians' expressed attitudes towards faculty. The Reference Librarian, 43(89), 25-38.

Ivey, R. (1994). Teaching faculty perceptions of academic librarians at Memphis State University. College \& Research Libraries, 55(1), 69-82.

Julien, H., \& Given, L. M. (2003). Faculty-librarian relationships in the information literacy context: A content analysis of librarians' expressed attitudes and experiences. Proceedings of the Annual Conference of CAIS. Retrieved March 10, 2017, from https://www.cais-acsi.ca/ojs/index.php/cais/index

Julien, H., \& Pecoskie, J. J. (2009). Librarians' experiences of the teaching role: Grounded in campus relationships. Library \& Information Science Research, 31(3), 149-154.

Kaiser, C., \& Miller, C. (2001). Stop complaining! The social costs of making attributions to discrimination. Personality and Social Psychology Bulletin, 27(2), 254-263.

Kot, F., \& Jones, J. (2015). The impact of library resource utilization on undergraduate students' academic performance: A propensity score matching design. College \& Research Libraries, 76(5), 566-586.

Krosnick, J., Narayan, S., \& Smith, W. (1996). Satisficing in surveys: Initial evidence. New Directions for Evaluation, 70, 29-44.

Kuh, G. D., \& Gonyea, R. M. (2003). The role of the academic library in promoting student engagement in learning. College \& Research Libraries, 64(4), 256-282.

LIS Microaggressions. (n.d.). Zines. Retrieved September 10, 2016, from http: // lismicroaggressions.tumblr.com/zines

Mounce, M. (2010). Working together: Academic librarians and faculty collaborating to improve students' information literacy skills: A literature review 2000-2009. The Reference Librarian, 51(4), 300-320.

Nalani Meulemans, Y., \& Carr, A. (2013). Not at your service: Building genuine faculty-librarian partnerships. Reference Services Review, 41(1), 80-90.

Pierce, C. (1970). Offensive mechanisms. In F. B. Barbour (Ed.), The black seventies (pp. 265282). Boston, MA: Porter Sargent Publisher.

Rowe, M. (1981). The minutiae of discrimination: The need for support. In B. L. Forisha \& B H. Goldman (Eds.), Outsiders on the inside: Women \& organizations (pp. 155-170). Englewood Cliffs, NJ: Prentice-Hall. 
Stemmer, J., \& Mahan, D. (2016). Investigating the relationship of library usage to student outcomes. College \& Research Libraries, 77(3), 359-375.

Sue, D. W. (2010). Microaggressions and marginality: Manifestation, dynamics, and impact. Hoboken, NJ: Wiley.

Sue, D. W., Capodilupo, C. M., Torino, G. C., Bucceri, J. M., Holder, A. M. B., Nadal, K. L., \& Esquilin, M. (2007). Racial microaggressions in everyday life. American Psychologist, 62(4), 271-286.

Sue, D. W., \& Rivera, D. P. (2010). Microaggressions: More than just race: Can microaggressions be directed at women or gay people? Retrieved from https: / / www.psychologytoday.com/us/blog/microaggressions-in-everydaylife/201011/microaggressions-more-just-race

Vassilakaki, E., \& Moniarou-Papaconstantinou, V. (2015). A systematic literature review informing library and information professionals' emerging roles. New Library World, 116(1/2), 37-66.

Ahmed Alwan (ahmed.alwan@csun.edu) is a faculty member at California State University, Northridge (CSUN) and a Research, Instruction and Outreach Librarian in the Oviatt Library. In the most recent years leading up to his appointment at CSUN, Ahmed was the Information Literacy Librarian at the American University of Sharjah in the United Arab Emirates. Ahmed has a Bachelor of Arts in History and Religious Studies from York University, and a Master of Information Science from the University of Toronto.

Joy Doan (joymdoan@northwestern.edu) is a Librarian at Northwestern University's Music Library. Prior to joining Northwestern, Joy held a position at California State University, Northridge (CSUN) and the University of California, Los Angeles (UCLA). Joy holds a Bachelor of Arts in English Literature and Music from the University of Michigan, an M.A. in Music History from Case Western Reserve University, and a Master of Library and Information Science degree from San Jose State University.

Eric P. Garcia (eric.garcia@csun.edu) is a tenured faculty member at California State University, Northridge (CSUN) and a Research, Instruction and Outreach Librarian in the Oviatt Library teaching Information Literacy courses. His research interest includes information literacy instruction, assessment of library services, and examining the contributing factors of academic libraries have on student success. Eric has a Bachelor of Arts in History, Masters in History, Masters of Library \& Information Science, and is currently working towards a Ph.D. in Higher Education. 